\title{
Post Reform Trends in Profitability in Crop Cultivation in Kerala: Evidences from the Cost of Cultivation Survey Data
}

\author{
Ranjith Mathew Abraham ${ }^{1 *}$ and Ashish Varughese ${ }^{2}$ \\ ${ }^{1}$ Associate Professor, Department of Economics, Bishop Moore College, Mavelikara, Kerala, India \\ 2Asst. Professor, Department of Commerce, Bishop Moore College, Mavelikara, Kerala, India \\ *Corresponding author: ranjithmathewabraham@gmail.com (ORCID ID: 0000-0002-6740-200X)
}

Received: $15-09-2021$

Revised: 20-11-2021

Accepted: $10-12-2021$

\begin{abstract}
Profitability is the major objective of any farm or firm. The high wage rate in the state and the rapid rise in the cost of cultivation have raised questions regarding the profitability of crop cultivation in Kerala. The post reform period has been a period of agrarian distress with falling prices and declining income of the farmers There has been a tendency for the farmer to withdraw from paddy cultivation in Kerala due to uneconomic returns.. Cultivation of paddy and other annual crops is a losing proposition. In the background of this context, this study attempts to compute the profitability of crop cultivation of seven selected crops in the state. The data published in the Cost of Cultivation reports of the Department of Economics and Statistics, Government of Kerala is used in this study. Though there has been a rapid increase in wage rate and the cost of cultivation, the study shows that the gross value of output has increased faster. The farmer being rational has resorted to coping strategies like reducing the percentage of hired human labour in the total operational cost. When considering Cost A, crop cultivation has been profitable, but while considering cost B, crop cultivation has been highly unprofitable. The rapid increase in the value of land is the prime cause for the spiraling increase in cost B. Banana, Pepper and tapioca has been the most profitable crops in the state. The profitability of paddy crop has not been commensurate when compared to the profit accruing to other crops in Kerala. Any effort to increase the area under paddy cultivation must provide price and non-price incentives to the farmers.
\end{abstract}

\section{HIGHLIGHTS}

(0 The post reform period witnessed a rapid rise in agricultural wage rates.

0 The cost of cultivation increased rapidly in the post reform period.

(0 The rapid increase in the value of land is the prime cause for the spiraling increase in cost B.

0 Banana, pepper and tapioca has been the most profitable crops in the state respectively.

( The profitability of paddy crop has been not been commensurate when compared to the profit accruing to other crops in Kerala.

Keywords: Cost of cultivation, hired human labour cost, gross value of output per hectare, net value of output per hectare, relative crop profitability, profit from crop cultivation, interest on land value

The post reform period in the Indian economy has been detrimental to Indian agricultural sector due to the crisis caused by rising input cost, declining prices and absence of alternative livelihood sources. Farmer suicides, indebtedness, crop failures, unremunerative prices for crops and poor returns over cost of cultivation are the prominent features of Indias agriculture today. It is estimated that over two lakh farmers committed suicides in India between 1990-91 and 2009-10 (Sainath, 2010). The failure of the government to provide agricultural loans to the farmers at low interest rates and the

How to cite this article: Abraham, R.M. and Varughese, A. (2021). Post Reform Trends in Profitability in Crop Cultivation in Kerala: Evidences from the Cost of Cultivation Survey Data. Economic Affairs, 66(04): 671 678.

Source of Support: None; Conflict of Interest: None 
high prices of agricultural inputs dragged the cultivating households into the clutches of private moneylenders (Bagchi, 2004). The agrarian economy of Kerala has also been under severe stress in the first decade of this century as the prices of major crops have witnessed wild fluctuations with sharp fall in successive years (Subramaniam, 2007). In the post WTO period, the domestic prices of plantation crops appear to be strongly correlated to the movement of international prices. The sharp fall in agricultural prices have subjected the farmers to unprecedented price risk and uncertainity. This is aggravated by thefact that this period has been characterized by adverse weather conditions and low yields (Nair et al. 2007). The post reform period have opened up the agricultural sector to the vagaries of the market resulting in violent fluctuations in the prices of agricultural commodities. The farmer is always forced to sell his produce at a very low price and thereby suffers huge losses. The rapid fluctuation in prices of agricultural commodities and the resulting decline in profits call for an intervention of the government in agricultural markets.

Schultz (1964) was the foremost proponent of the traditional neo-classical theory. Within the limitation of 'traditional agriculture' Schultz regarded farmers as rational, profit maximizing entrepreneurs who respond quickly, normally and efficiently to price changes. The implication is that every farmer is rational and he will allocate resources towards each crop by evaluating the price received and the cost incurred for the crop. However Schultz was criticized by Scott (1976) and Popkin (1979) for the notion of rational, profit maximizing farmer. Scott rejects the profit maximization calculus of traditional neoclassical economics and advances the importance of the subsistence motive, which he calls the 'safetyfirst' principle. Popkin reemphasises that farmers strive to not only protect but raise their subsistence level through long and short term investments. The neo classical theory assumes that farmers are profit maximisers who have complete information of farm inputs and outputs, unlimited working capital for the purchase of inputs; substitutability of inputs and outputs. Thus, according to neoclassical theory farmers allocate their inputs efficiently, produce the most profitable mix of crops, intensify production optimally according to economic calculations, and apply the least cost method of production (Ellis, 1988).
Government intervention in agricultural markets takes the form of price support, procurement operations, subsidy schemes and control of acreage under a crop. Government assures a minimum support price for the cultivator or otherwise a maximum price for the benefit of the consumers. These interventions in the market by the Government necessitate the study of cost of cultivation and the relative profitability of different crops. The relative profitability influences the allocation of resources among alternative crops. Studying about returns from crop cultivation is also important from the fact that they also facilitate investment in agriculture. If returns are not regular and inadequate, farmers may not be able to repay their debts, which would lead to increased indebtedness. These issues necessitate a study on the hired labour cost, wage rate, profitability, cost of cultivation and percentage of returns from crops cultivation in Kerala. The objective of this paper is to study the changes in the cost of cultivation during the post reform period, secondly to compute the profits made in crop cultivation and to estimate the percentage of returns over cost in the cultivation of crops in kerala.

\section{Methodology}

This study is based on the Cost of Cultivation data of different crops published by the Department of Economics and Statistics, Government of Kerala in the Report on the Cost of Cultivation of Important Crops in Kerala" for various years. The crops included in the study are paddy autumn, paddy winter, paddy summer, coconut, banana, pepper, tapioca, ginger and turmeric. The methodology used for the computation of cost of cultivation categorizes the cost of cultivation in to Cost A, Cost B and Cost C. Cost A is the total paid out cost (both cash and kind expenses) of the farmers which include the expenditure on hired lab our and inputs used in the cultivation of the crop. Cost B is defined as cost A plus interest on fixed capital including land. Profitability of the crop is arrived at by deducting the cost of cultivation per hectare from the gross value of output per hectare. The period considered for the study extends from 2000-01 to 2016-17 which corresponds to the post reform period. We consider five points of time during the period under study for our analysis. There is no significant difference between the cost $B$ and cost $C$ estimates 
as the imputed value of family labour is relatively small, therefore in our analysis we present only the estimated value of cost A and cost B. Simple percentage analysis is used to bring out the changes in the variables between 2000-01 and 2015-16.

\section{Review of Literature}

George PS has highlighted the conceptual difficulties in computing the cost of cultivation. There are number of problems in estimating the cost of cultivation of individual crops, especially in relation to identification of the items of cost, valuation of different items and specification of the reference group of cultivators. The cost data in Kerala has been highly misrepresented due to the introduction of the notional value of land in the calculation of Cost $B$ and Cost $C$ concepts. Interest on land value accounted for about half the total cost for paddy and ginger, and the share was above $85 \%$ for coconut, pepper, tapioca and arecanut (George, 1988). Raghavan found that in the post reform period there has been a steep decline in the labour hours applied in cultivation as also stagnation in casual wages. The agrarian crisis in the post reform period afflicted not only the cultivating households but also the entire agriculture dependent population. There was a deceleration in the rate of growth of chemical fertilizers applied in cultivation, but a rapid acceleration in the cost of fertilizers. The study revealed that the cost of cultivation increased faster than the increase in the general price level (Raghavan 2008). Another study also found that farmers have suffered substantial losses in the cultivation of different crops during the post reform period (Narayanamoorthy 2013). Swaminathan opined that farmers have suffered losses both due to increased cost of cultivation in some crops and due to reduction in value of output in some other crops. Continuous suffereing of losses would definitely discourage farmers from engaging in agriculture (Swaminathan, 2008). There are very few studies that have done a detailed analysis of the profitability of different crops in relation to cost of cultivation over a period of time. Some studies have shown that the stagnation in real income and relatively higher rise in input prices, than the prices of the agricultural produce could be the reason for farmer suicides (Kalamkar and Narayanamoorthy, 2003; Narayanamoorthy 2006;2007; Deshpande and
Arora, 2010; Sainath, 2010; NCF, 2006. One study has attempted to calculate the profitability of six different crops from different states using temporal data compiled from the various reports of the CACP (Narayanamoorthy. 2013).

\section{DISCUSSION}

\section{Rise in Agricultural wages and hired labour cost}

Kerala is a state where the wages of agricultural labour is among the highest in the country itself. The wage rate of male unskilled agricultural worker was ₹ 123.15 in 2000-01 which increased to ₹ 608.29 in 2016-17 recording an increase of $393 \%$ over the period. In the case of wages of female unskilled agricultural worker the wage rate increased from ₹ 82.38 in $2000-01$ to ₹ 447.85 in $2016-17$ marking an increase of $443.6 \%$. The field crops like paddy are highly female labour intensive making it very difficult to sustain the cultivation of the crop due to the high wage rate.

Table 1: Average daily wage rate (₹) of unskilled workers (paddy field workers) in agricultural sector

\begin{tabular}{lll}
\hline Year & Male & Female \\
\hline $2000-01$ & 123.15 & 82.38 \\
$2005-06$ & 166.39 & 108.19 \\
$2010-11$ & 312.82 & 228.48 \\
$2015-16$ & 586.06 & 422.19 \\
$2016-17$ & 608.29 & 447.85 \\
Percentage change & 393.94 & 443.64 \\
\hline
\end{tabular}

Source: Economic Review, various issues.

The hired labour cost of pepper increased from ₹ 8185 in 2000-01 to ₹ 46279 in 2016-17 recording an increase of $465 \%$ during the period under consideration. The percentage increase in hired human labour cost of paddy Autumn, paddy winter and paddy summer was only $142 \%, 195 \%$ and $105 \%$ which is not consistent with increase in the wage rate of agricultural labourers. This shows that the farmer has resorted to coping strategy of substituting the agricultural hired labourer with increased use of capital in the post reform period. The table 3 showing the wage cost as a percentage of the operational cost shows that the expenditure on wage cost as a percentage of operational cost has declined consistently over the period. This 
Table 2: Total hired human labour (₹/hectare)

\begin{tabular}{lllllll}
\hline Crops & $\mathbf{2 0 0 0 - 0 1}$ & $\mathbf{2 0 0 5 - 0 6}$ & $\mathbf{2 0 1 0 - 1 1}$ & $\mathbf{2 0 1 5 - 1 6}$ & $\mathbf{2 0 1 6 - 1 7}$ & Percentage change \\
\hline Paddy (A) & 10571 & 9782 & 16833 & 25041 & 25474 & 140.98 \\
Paddy (W) & 8615 & 9967 & 20202 & 24656 & 25234 & 192.91 \\
Paddy (S) & 10686 & 9851 & 17211 & 24470 & 22006 & 105.93 \\
Coconut & 7328 & 11069 & 19750 & 37028 & 40918 & 458.37 \\
Banana & 26683 & 31403 & 31977 & 74767 & 73597 & 175.81 \\
Pepper & 8185 & 10787 & 22465 & 34186 & 46279 & 465.41 \\
Tapioca & 15672 & 13476 & 31293 & 46627 & 50285 & 220.86 \\
Ginger & 17260 & 20553 & 38333 & 64038 & 87076 & 404.49 \\
Turmeric & 14483 & 17116 & 27333 & 32455 & 46802 & 223.15 \\
\hline
\end{tabular}

Source: Report on Cost of Cultivation of Important Crops in Kerala, Dept. of Economics and Statistics, Govt. of Kerala, Various issues.

Table 3: Wage cost as percentage of Operational cost

\begin{tabular}{llllll}
\hline Crops & $\mathbf{2 0 0 0 - 0 1}$ & $\mathbf{2 0 0 5 - 0 6}$ & $\mathbf{2 0 1 0 - 1 1}$ & $\mathbf{2 0 1 5 - 1 6}$ & $\mathbf{2 0 1 6 - 1 7}$ \\
\hline Paddy (A) & 61.42 & 51.56 & 52 & 48.32 & 48.23 \\
Paddy (W) & 52.79 & 52.20 & 49 & 44.79 & 42.34 \\
Paddy (S) & 52.72 & 49.12 & 45 & 41.79 & 40.67 \\
Coconut & 56.67 & 53.85 & 59 & 60.28 & 61.02 \\
Banana & 29.04 & 41.28 & 38 & 42.39 & 40.23 \\
Pepper & 58.73 & 54.28 & 59 & 57.87 & 60.09 \\
Tapioca & 62.43 & 53.61 & 64 & 54.61 & 52.44 \\
Ginger & 31.92 & 33.24 & 34 & 32.62 & 37.01 \\
Turmeric & 44.81 & 44.16 & 46 & 44.08 & 38.76 \\
\hline
\end{tabular}

Source: Report on Cost of Cultivation of Important Crops in Kerala, Dept. of Economics and Statistics, Govt. of Kerala, Various issues.

could be because the farmer has resorted to coping strategy like reducing the number of labourers and increasing the mechanization in cropping activities. On the other hand crops like coconut and pepper the scope for mechanization has been lesser and there has been an increase in the percentage of hired human labour cost.

The total hired human labour cost per hectare was the highest in Banana and ginger cultivation during 2000-01. In 2016-17 also the two crops banana and ginger continued to be the crop with the highest total hired human labour cost per hectare. Pepper and coconut crop recorded the highest percentage increase in total hired human labour cost in the post reform period. The total hired human labour cost of pepper increased by $465 \%$ and that of coconut increased by $458 \%$. The hired human labour cost increased by $140 \%, 192 \%$ and $105 \%$ in respect of Paddy autumn, Paddy winter and Paddy summer. Ginger is another crop for which the cost of hired human labour increased by $404 \%$. The increase in the total hired human labour cost could be due to two reasons. Firstly the increase in the wage rate of agricultural workers and the secondly is the increased usage of labour. The data on agricultural wages of male and female workers show that the wage increased tremendously during the period under consideration. The wage cost as percentage of operational cost has shown a consistently declining trend in the case of annual crops like paddy, tapioca, ginger and turmeric. In Paddy autumn the wage cost comprised 61.42 percentage of operational cost in 2000-01, which was only $48.23 \%$ in 2016-17. Paddy winter and paddy summer also witnessed a similar decline in wage cost as a percentage of operational cost. Whereas in the case of crops like coconut and pepper which have a longer lifespan the share of wage cost showed an increasing trend. The labour cost as percentage of operational cost was $61 \%$ and $60 \%$ for coconut and pepper respectively. The table 2 shows the cost incurred on total hired labour in the cultivation of crops.

Rise in Cost of Cultivation: The table 4 shows the estimates of cost $\mathrm{A}$ and the figures in parenthesis are 
Table 4: Estimates of Cost $A$ and Cost $B$ per hectare. In each case the first value corresponds to cost $A$ and the value in paranthesis corresponds to cost $\mathrm{B} .(₹)$

\begin{tabular}{lllllll}
\hline Crops & $\mathbf{2 0 0 0 - 0 1}$ & $\mathbf{2 0 0 5 - 0 6}$ & $\mathbf{2 0 1 0 - 1 1}$ & $\mathbf{2 0 1 5 - 1 6}$ & $\mathbf{2 0 1 6 - 1 7}$ & $\begin{array}{l}\text { 2000-01 to 2016-17 } \\
\text { percentage change } \\
\text { (cost A) }\end{array}$ \\
\hline Autumn paddy & $17210(36568)$ & $18971(40319)$ & $32019(91877)$ & $51823(95647)$ & $52818(105157)$ & 206.90 \\
Winter Paddy & $16318(31154)$ & $19094(44933)$ & $41133(122697)$ & $55044(94977)$ & $59600(114661)$ & 265.24 \\
Summer Paddy & $20270(30400)$ & $20057(38598)$ & $37957(86712)$ & $58555(102857)$ & $54109(98745)$ & 166.94 \\
Coconut & $12955(165318)$ & $20555(204220)$ & $33343(538739)$ & $61429(386208)$ & $67062(386171)$ & 417.65 \\
Banana & $91853(149356)$ & $76080(216930)$ & $104903(443736)$ & $176400(354317)$ & $182921(414249)$ & 99.14 \\
Pepper & $13938(185638)$ & $19874(276448)$ & $38052(429123)$ & $59074(224842)$ & $77019(300157)$ & 452.58 \\
Tapioca & $25102(128055)$ & $25136(166303)$ & $48474(434258)$ & $85382(296023)$ & $95899(313192)$ & 282.04 \\
Ginger & $54082(134790)$ & $61835(176939)$ & $112123(430826)$ & $196316(330415)$ & $235296(414121)$ & 335.07 \\
Turmeric & $32320(115232)$ & $38762(284611)$ & $59707(462861)$ & $73625(198309)$ & $120755(347665)$ & 273.62 \\
\hline
\end{tabular}

Source: Report on Cost of Cultivation of Important Crops in Kerala, Dept. of Economics and Statistics, Govt. of Kerala, Various issues.

Table 5: showing the Value of output per hectare (₹ per hectare)

\begin{tabular}{lllllll}
\hline Crops & $\mathbf{2 0 0 0 - 0 1}$ & $\mathbf{2 0 0 5 - 0 6}$ & $\mathbf{2 0 1 0 - 1 1}$ & $\mathbf{2 0 1 5 - 1 6}$ & $\mathbf{2 0 1 6 - 1 7}$ & $\begin{array}{l}\text { Percentage change from } \\
\mathbf{2 0 0 0}-\mathbf{0 1} \text { to 2016-17 }\end{array}$ \\
\hline Paddy (A) & 19271 & 24001 & 41517 & 78675 & 86172 & 347.15 \\
Paddy (W) & 21298 & 26224 & 56819 & 93214 & 90072 & 322.91 \\
Paddy (S) & 24943 & 25861 & 56146 & 96869 & 86612 & 247.24 \\
Coconut & 21508 & 41746 & 64447 & 102791 & 128467 & 497.29 \\
Banana & 140433 & 118229 & 273531 & 452951 & 500319 & 256.26 \\
Pepper & 35688 & 32995 & 72206 & 322229 & 317987 & 791.01 \\
Tapioca & 39152 & 49377 & 137407 & 216662 & 309762 & 691.17 \\
Ginger & 68304 & 76215 & 215483 & 287423 & 319149 & 367.24 \\
Turmeric & 33061 & 57279 & 100837 & 149826 & 250017 & 656.22 \\
\hline
\end{tabular}

Source: Report on Cost of Cultivation of Important Crops in Kerala, Dept. of Economics and Statistics, Govt. of Kerala, Various issues.

cost B per hectare for the crops under consideration for five intermittent years during the post reform period. Both the cost $\mathrm{A}$ and cost $\mathrm{B}$ estimates are consistently increasing during the period. The highest increase in the cost $\mathrm{A}$ was witnessed in Pepper crop with an increase in the cost of cultivation from ₹ 13938 in 2000-01 to ₹ 77019 in 2016-17 with an increase of $452 \%$. This increase in cost of cultivation of pepper is very much consistent with the increase in wage rate of agricultural labourers. Coconut is another crop which witnessed an increase in the cost A from ₹ 12955 in 2000-01 to $₹ 67062$ recording a rise of $417 \%$. The increase in the cost A of Banana cultivation was the lowest with an increase of $99 \%$ during the period. The cost A of cultivation of paddy Autumn, paddy winter and paddy summer was $206 \%, 265 \%$ and $166 \%$ respectively. Cost A of ginger cultivation increased by $335 \%$ and that of tapioca increased by $282 \%$.
The cost of cultivation per hectare was the highest for Ginger with ₹ 235296 followed by banana cultivation with ₹ 182921 in 2016-17. For all the time points it was found that ginger and banana had the highest cost of cultivation per hectare. The rapid rise in the cost of cultivation calls for a government intervention in the market either in the minimum support price or in the form of assured inputs at subsidized prices.

Rapid rise in the value of output per hectare: The estimates of the gross value of output per hectare (Table 5) is the sum of the value of the output per hectare and the value of the byproduct per hectare which is published in the report on cost of cultivation of important crops in Kerala. The highest gross value of output per hectare was in banana cultivation with a value of ₹ 500319 in 201617. It can be seen that for all the time points under consideration the banana crop had the highest 
value of output per hectare. It is significant to note that the gross value of output was the lowest in paddy cultivation. The highest increase in the gross value of output was witnessed in pepper with an increase of $791 \%$, followed by tapioca and turmeric with an increase of $691 \%$ and $656 \%$ respectively. Paddy Autumn, paddy winter and paddy summer witnessed an increase of $347 \%, 322 \%$ and $247 \%$ respectively. The gross value of output is influenced by the productivity and price of the crop.

Net returns per hectare or relative profitablility: The net returns per hectare or the relative profitability of the crop is arrived at by deducting the cost A of cultivation from the gross value of output per hectare. The net returns per hectare for all the crops under consideration is presented in table 6. Banana was the most profitable crop in all the time points under consideration. The profit per hectare in banana cultivation was ₹ 48580 in 200001 which increased to ₹ 317398 in 2016-17. The profit of Pepper cultivation increased from ₹. 21750 in 2000-01 to ₹ 240968 in 2016-17. Pepper was the second most profitable crop for all the time points under consideration. The profit of paddy cultivation increased consistently for all the years, but when compared to other crops it was the least profitable crop in the state. The low profitability could be the reason for the rapid and consistent fall in the area under cultivation of paddy crop in the state. Any attempt to increase the area under paddy cultivation in the state of Kerala requires steps to increase the profitability of the crop when compared to other field crops.

Profit from crop cultivation: The cost A consist of cash and kind expenses (paid out costs) actually incurred by the cultivator. This include expenses incurred for hired human labour, animal labour, machine labour, seeds, farm yard manure, plant protection, land tax, irrigation tax, repair and maintenance, interest on working capital, other expenses. The percentage of profit over the cost A of cultivation shows that pepper crop with a profit of

Table 6: Profit per hectare based on cost A and the figures in parenthesis are profit per hectare based on Cost B

(₹ per hectare)

\begin{tabular}{llllll}
\hline Crops & $\mathbf{2 0 0 0 - 0 1}$ & $\mathbf{2 0 0 5 - 0 6}$ & $\mathbf{2 0 1 0 - 1 1}$ & $\mathbf{2 0 1 5 - 1 6}$ & $\mathbf{2 0 1 6 - 1 7}$ \\
\hline Paddy (A) & $2061(-17297)$ & $5030(-16318)$ & $9498(-50360)$ & $26852(-26482)$ & $33354(-18985)$ \\
Paddy (W) & $4980(-9856)$ & $7130(-18709)$ & $15686(-65878)$ & $38170(-1763)$ & $30472(-24589)$ \\
Paddy (S) & $4673(-5457)$ & $5804(-12737)$ & $18189(-30566)$ & $38314(-1876)$ & $32503(-12133)$ \\
Coconut & $8553(-143810)$ & $21191(-162474)$ & $31104(-474292)$ & $41362(-283417)$ & $61405(-257704)$ \\
Banana & $48580(-8923)$ & $42149(-98701)$ & $168628(-170205)$ & $276551(98634)$ & $317398(86070)$ \\
Pepper & $21750(-149950)$ & $13121(-243453)$ & $34154(-356917)$ & $263155(97387)$ & $240968(17830)$ \\
Tapioca & $14050(-88903)$ & $24241(-116926)$ & $88933(-296851)$ & $131280(-79361)$ & $213863(-3430)$ \\
Ginger & $14222(-66486)$ & $14380(-100724)$ & $103360(-215343)$ & $91107(-42992)$ & $83853(-94972)$ \\
Turmeric & $741(-82171)$ & $18517(-227332)$ & $41130(-362024)$ & $76201(-48483)$ & $129262(-97648)$ \\
\hline
\end{tabular}

Source: Computed.

Table 7: Showing the Profit percentage based on cost A

\begin{tabular}{llllll}
\hline Crops & $\mathbf{2 0 0 0 - 0 1}$ & $\mathbf{2 0 0 5 - 0 6}$ & $\mathbf{2 0 1 0 - 1 1}$ & $\mathbf{2 0 1 5 - 1 6}$ & $\mathbf{2 0 1 6 - 1 7}$ \\
\hline Paddy (A) & 11.97 & 26.51 & 29.66 & 51.81 & 63.14 \\
Paddy (W) & 30.51 & 37.34 & 38.13 & 69.34 & 51.12 \\
Paddy (S) & 23.05 & 28.93 & 47.92 & 65.43 & 60.06 \\
Coconut & 66.02 & 103.09 & 93.28 & 67.33 & 91.56 \\
Banana & 52.88 & 55.40 & 160.74 & 156.77 & 173.51 \\
Pepper & 156.05 & 66.02 & 89.75 & 445.46 & 312.86 \\
Tapioca & 55.97 & 96.43 & 183.46 & 153.75 & 223.00 \\
Ginger & 26.29 & 23.25 & 92.18 & 46.40 & 35.63 \\
Turmeric & 2.29 & 47.77 & 68.88 & 103.49 & 107.04 \\
\hline
\end{tabular}

Source: Computed. 
$156 \%$ was the crop with the highest returns over the cost of cultivation in 2000-01. Coconut had a return of $66 \%$ and tapioca fetched a return of $56 \%$ over the cost of Cultivation in 2000-01. Paddy showed returns of less than 30\% during 2000-01. During the first two time periods the rate of profit over cost was very low, which could be due to the price crash and the agrarian distress during this period. The rate of profit over cost A consistently increased for all the crops. During 2016-17 pepper continued to fetch the highest percentage of profit over cost at $312 \%$. Tapioca fetched a profit over cost A of $223 \%$ followed by banana with $173 \%$. Though the profit rate of paddy increased for all seasons it was among the least profitable crop in the state. The relative profitability of the crops clearly indicated why the area under paddy is dwindling in the state.

Profits when interest on land value is considered: Any discussion on agricultural cost would be incomplete without mentioning about the interest on land value. Cost B is the sum of all operational cost plus the interest on fixed assets and the interest on land value. The interest on land value is considered for the computation of Cost B. when cost $\mathrm{B}$ is considered for the computation of profit rate almost all crops show a loss, except for banana and pepper in the final two time periods. In an earlier study Joseph (2004) found that agricultural land prices are so high in Kerala that if interest on land value is added to the paid out cost of cultivation none of the major crops cultivated in the state is economically viable. The rationality of using interest on land value to compute cost of cultivation has been questioned, because land value is seen to appreciate every year in stark contrast to the allowances made for depreciation of capital in the industrial sector. The argument is that capital assets depreciate, whereas land value appreciates then why do we include interest on land value as a cost incurred in the computing of cost of cultivation. The land value appreciate due to several factors external to the agricultural sector (speculative aspects of investiment in land) and is not appropriate to include the notional costs in the computation of cost of cultivation. The shortage of land suitable for house construction, the high density of population and the large influx of gulf returnees have made the land market highly speculative (Oommen, 1993). Further no cultivator would be willing to pay capital gains tax on the basis of the notional value of land. Therefore it is argued that the practice of using the current value of land in estimating the cost of cultivation is conceptually inappropriate. Instead of using market value of land to compute interest of land value, it would be more appropriate if rent entitlements on land are used (George, 1988).

The other argument is that there is some justification in using the interest on land value as an element of cost of cultivation. The logic is that if money is invested anywhere else it would have brought some returns and should therefore take into account the element of interest on land value in the cost of cultivation. If farming is to be considered a success when undertaken on commercial terms the following requirements have to be fulfilled. One, it must generate income to pay all farm expenses, second, it must be able to pay the prevailing interest rate on capital invested, third, it must pay reasonable wages to the farmer and lastly it must leave the farm as productive at the close of the year as it was in the beginning of the years operation (Efferson, 1953). The results show that when Cost $\mathrm{B}$ is taken into account the profit from cultivation is negative for almost all the crops and all the time period. The situation is not different when cost $C$ is taken into account.

\section{CONCLUSION}

The post reform period has witnessed a rapid rise in the wage rate of both male and female agricultural labourers. The first two time period from 2000-01 and 2005-06 corresponds to the period of agrarian distress in Kerala when agricultural incomes, wages and and profits were considerably low. Farmers have consistently reduced the hired human labour hours used in cultivation of crops. For almost all crops the hired human labour has consistently declined, or the cultivator has resorted to coping strategy of substituting human labour with machines. Farmers have consistently reduced the extent of wage labour as percentage of total operational cost. This phenomena has been seen in all the annual and field crops. However when the whole period is concerned the post reform period has been favourable to the farmer in Kerala. The cost of cultivation has been the highest for ginger and banana among the crops considered. The value of output per hectare was the highest for banana, ginger, tapioca . Banana, 
Pepper and tapioca has been the most profitable crops in the state. The profitability of paddy crop has been not been commensurate when compared to the profit accruing to other crops in Kerala. Any effort to increase the area under paddy cultivation must provide price and non-price incentives to the farmers. The farmers must be given sustained support in the form of increased net returns from their crop cultivation. The prices of the crops must be fixed by taking into account the cost of cultivation of the crops. An allowance must be provided to take into account the land value in the cost of cultivation and in the fixation of Minimum support price for the crops. The farmers must be protected from distress sale during glut periods by making government intervention in the market.

\section{REFERENCES}

Bhagchi, Amiya Kumar. 2004. The Common Minimum Programme. Social Scientist. July-August, pp. 3-16.

Bhalla, G.S. and Singh, G. 2009. Economic Liberalization and Indian agriculture: A State-wise analysis. Eco. and Pol. Weekly, 44(52): 34-44.

Deshpande, R.S. and Arora, S. (Ed.) 2010. Agrarian Crisis and Farmer Suicides, Sage Publications, New Delhi.

Efferson, N. 1953. Principles of Farm Management, Mcgraw Hill.

Ellis, F. 1988. Peasant Economics. Cambridge University Press. Cambridge.

George, P.S. 1988. Dilemma of Cost of Cultivation in Kerala. Eco. and Pol. Weekly, pp. A-129-132.

Joseph, S. 2004. Flow of Credit to Trade and Commerce in Kerala. PhD Thesis. Mahatma Gandhi University, Kottayam.
Kalamkar, S.S. and Narayanamoorthy, A. 2003. Impact of Liberalization on Domestic Agricultural Prices and Farm Income. Indian J. Agric. Eco., 58(3): 353-364.

Nair, K.N., Vinod, C.P. and Vineetha, M. 2007. Agrarian Distress and Livelihood Strategies: A Study on Pulpalli Panchayat, Wayanad District, Kerala. Working paper No. 396, Centre for Development Studies, Thiruvananthapuram.

Narayanamoorthy, A. 2013. Profitability in Crops Cultivation in India: Some Evidence from Cost of Cultivation Survey Data. Indian J. Agric. Eco., 68(1): 104-120.

NCF. 2006. Serving Farmers and Saving Farming Report V Excerpts, The National Commission on Farmers, Ministry of Agriculture, Government of India, New Delhi (www. krishakayog.gov.in).

Oommen, M.A. 1993. The Acute Unemployment Problem of Kerala -Some Exploratory Hypothesis. In Oommen,M.A (Ed), Essays on Kerala Economy, Oxford and IBH publishing, New Delhi.

Popkin, Samuel L. 1979. The Ratiional Peasant: The Political Economy of Rural Society in Vietnam. University of California press. Berkeley and Los Angeles.

Raghavan, M. 2008. Changing Pattern of Input Use and Cost of Cultivation. Eco. and Pol. Weekly., Review of Agriculture, June 28, pp. 123-129.

Sainath, P. 2010. "Farm Suicides - A 12 year Saga", The Hindu, Jan 2.

Schultz, T.W. 1964. Transforming Traditional Agriculture, Chicago University Press, Chicago.

Subramanian, K.K. 2007. Impact of the Plantation Crops of South India: Export Performances and Price Instability, unpublished paper, centre for Development Studies, Thiruvananthapuram.

Swaminathan, M.S. 2008. Ending the Debt Trap and Attaining Food Security. The Hindu, March 3, pp. 12. 